\section{Hjelp for spesialistkandidater i lungemedisin}

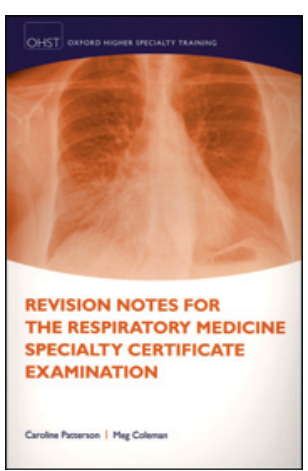

Caroline Patterson, Meg Coleman

Revision notes for the respiratory medicine specialty certificate examination

$121 \mathrm{~s}$, tabs, ill. Oxford: Oxford University Press, 2012. Pris GBP 35

ISBN 978-0-19-969348-1

I Storbritannia er ett av kravene i spesialistutdanningen for leger å bestå en eksamen innen det aktuelle faget. Boken er ment som en hjelp til dem som forbereder seg til spesialisteksamen i lungemedisin. Forfatterne er selv lungespesialister.

Det er tre deler. Første del omfatter 50 oppgaver med fem svaralternativer, slik spesialisteksamenene gjennomføres. Oppgavene dekker alle områder av lungemedisinen med tilsvarende intern fordeling innen fagområdet som ved eksamen. Det innebærer at for eksempel obstruktive lungesykdommer og lungekreft utgjør henholdsvis $12 \%$ og $10 \%$ av oppgavene. De fleste oppgavene er lagt opp som korte kasuistikker med aktuelle laboratorieprøver, svar på respirasjonsfysiologiske undersøkelser og ofte røntgenbilder eller computertomografi (CT)-bilder av thorax. Bildene må man selv tolke.

Den andre delen er en kort gjennomgang av retningslinjer for utredning, behandling og oppfølging av de viktigste tilstandene innen lungemedisinen. Den tredje og siste delen består av svar på oppgavene i den første delen med begrunnelse for det aktuelle svaret og hvorfor alternative svar ikke er korrekte. Endelig er det et register på slutten.

Boken representerer et godt forsøk på å forberede spesialistkandidatene i lungemedisin på eksamen. Kasuistikkene og svaralternativene er meget gode, og man kjenner seg igjen i flere av problemstillingene. Den svakeste delen er den summariske gjennomgangen av retningslinjer for ulike tilstander innen lungefaget. Disse retningslinjene er omtalt på over 80 sider, men det blir litt for kort. Dermed blir viktige sider av ulike tilstander ikke omtalt. For eksempel nevnes ikke komorbiditet ved kronisk obstruktiv lungesykdom med et ord. Registeret på slutten er også for kort.

Selv om del to er svak, er oppgavene absolutt verd å prøve seg på, enten man skal ta eksamen eller ikke. Boken kan også være et greit utgangspunkt for dem som lager eksamensoppgaver i indremedisin.

\section{Per S. Bakke}

Lungeavdelingen

Haukeland universitetssykehus

\section{Solid epilepsibok}

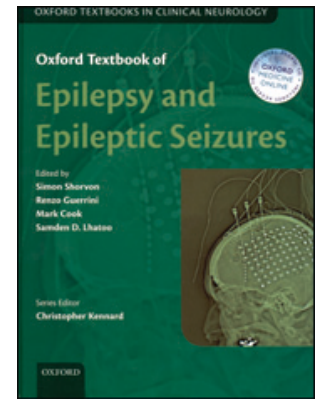

Simon Shorvon, Renzo Guerrini,

Mark Cook et al, red.

Oxford textbook of epilepsy and epileptic seizures

384 s, tab, ill. Oxford: Oxford University Press, 2013. Pris GBP 125

ISBN 978-0-19-965904-3

For de som er eller ønsker å bli epileptologer, har Engel og Pedleys Epilepsy. A comprehensive textbook lenge vært et «must». Det er et trebinds verk på ca. 3000 sider. For mange nevrologer og nevropediatere som ikke utelukkende behandler pasienter med epilepsi, er trolig den læreboken for omfattende.

Denne boken derimot, Oxford textbook of epilepsy and epileptic seizures, er mer overkommelig. Boken inngår i en bokserie kalt Oxford textbooks in clinical neurology. De fire hovedforfatterne er velrennomerte epileptologer, og de har knyttet til seg 51 medforfattere.

Leseren får en god oppdatering på de mest sentrale feltene av epileptologien. Forfatterne viser på en utmerket måte den store spennvidden i dette faget - fra det molekylærbiologiske grunnlaget for anfall til de psykososiale problemene som ofte følger i kjølvannet av en epilepsidiagnose.

Etter noen innledende kapitler om nevroanatomiske, nevrofysiologiske, nevrokjemiske og nevrogenetiske substrat for epilepsi følger kapitler om epidemiologi, etiologi, klassifikasjon, diagnostikk, differensialdiagnostikk og farmakologisk og ikke-farmakologisk behandling, inkludert epilepsikirurgi. Epilepsi blant små barn, mennesker med utviklingshemning, gravide og eldre er viet egne kapitler, likeså seksuelle problemer, psykiatrisk komorbiditet og status epilepticus.

Som de fleste lærebøker med mange forfattere, er det noe varierende kvalitet på kapitlene. Likevel synes jeg boken gjennomgående er velskrevet og informativ.

Simon Shorvon er en av vår tids fremste epileptologer. Jeg stusset derfor over at han i et kapittel om årsaker til epilepsi opererer med begrepet «provoked epilepsies». Dette begrepet omfatter epileptiske anfall utløst av feber (feberkramper), alkohol (abstinenskramper), visse medikamenter, metabolske forstyrrelser m.m. Slike anfall har vi, i hvert fall her i Norge, regnet som provoserte epileptiske anfall, og personer med slike anfall fyller $i k k e$ kravene til epilepsidiagnosen.

Målgruppen er helsepersonell som behandler pasienter med epilepsi, og som ønsker å holde seg à jour med hva som skjer innen fagfeltet. Jeg synes boken treffer godt, og kan anbefale den - både som basisverk og som oppslagsbok.

Karl 0. Nakken

Avdeling for kompleks epilepsi - SSE

Oslo universitetssykehus 